\title{
AN ANALYSIS OF CUSTOMER'S SATISFACTION LEVEL TO THE QUALITY OF SERVICES PROVIDED BY REGIONAL WATER SUPPLY COMPANY (PDAM) OF KOLAKA REGENCY
}

\author{
Niar Astaginy \\ Universitas Sembilanbelas November Kolaka Medan \\ Email: niarastaginy@yahoo.com
}

\begin{abstract}
The study is devoted to identifying the customer's expectation for the service quality of the regional water supply company (PDAM) of Kolaka Regency, describing the customer's perception of its service quality, and projecting the managerial implication to improve the quality of its services. The analysis methods used are conformity level analysis and important performance analysis. The analysis indicates that the highest expectation of the customer rests on the continuous supply of water without rotation system. The best performance of the company in the customer's perception is in the explanation of the water system installation procedure which is simple and uncomplicated. Based on Important Performance Matrix, it is apparent that quadrant 1 (Primary priorities) has eight attributes, quandrant 2(maintained) has six attributies, quandrant 3(low priority) has four attributies and quandrant 4(excessive) has two attibuties.
\end{abstract}

\section{Keyword : Regional Water Supply Company}

\begin{abstract}
Abstrak
Studi ini dikhususkan untuk mengidentifikasi harapan pelanggan untuk kualitas layanan dari perusahaan penyedia air minum regional (PDAM) Kabupaten Kolaka, menggambarkan persepsi pelanggan terhadap kualitas layanannya, dan memproyeksikan implikasi manajerial untuk meningkatkan kualitas layanannya. Metode analisis yang digunakan adalah analisis tingkat kesesuaian dan analisis kinerja yang penting. Analisis menunjukkan bahwa harapan tertinggi pelanggan terletak pada pasokan air tanpa sistem rotasi. Kinerja terbaik perusahaan dalam persepsi pelanggan adalah penjelasan tentang prosedur instalasi sistem air yang sederhana dan tidak rumit. Berdasarkan Matriks Kinerja Penting, terlihat bahwa kuadran 1 (Prioritas utama) memiliki delapan atribut, quandrant 2 (dipelihara) memiliki enam atribut, quandrant 3 (prioritas rendah) memiliki empat atribut dan quandrant 4 (berlebihan) memiliki dua attibuties.
\end{abstract}

Kata kunci: Perusahaan Daerah Air Minum 
Jurnal Darussalam; Jurnal Pendidikan, Komunikasi dan Pemikiran Hukum Islam Vol. IX, No 1: 13-23. September 2017. ISSN: 1978-4767 (Cetak), ISSN: 2549-4171 (Online)

\section{A. Introduction}

The need for clean water is very important in people's lives, not only as a complementary element but also as an essential element of equal importance as well as rice and other primary needs. Considering water is a basic necessity in everyday life, water has an important role to support the prosperity and welfare of society. The availability of adequate water will encourage the development of the development sector in the community. Programs undertaken by PDAMs in both urban and rural areas have the objective of providing services to communities to obtain clean and healthy water for household and industrial purposes to support economic development and health status of the population.

In the context of improving urban water supply services in this case Regional Water Supply Company (PDAM) as a means entrusted to manage the distribution of clean water often have difficulty in maintaining the production of clean water installation, so that it affects the distribution of clean water to consumers both in terms of quantity and quality. This is closely related to the quality of service whose output will ultimately affect the level of customer satisfaction in this community as a user of clean water services. As one of the existing public companies in the region, PDAM is very necessary presence for the community, as well as the importance of PDAM presence in Kolaka District.

In his book Taufan (1999: 9). Tirta Dharma, No.86 / Tahun XX-October 1999, suggests that operation in maintenance of clean water that is less effective or less efficient will result in poor service quality. This condition will cause: 1) Reduced social welfare, economy and health, 2) diminished customer satisfaction and affects willingness to pay, 3) stalled funds and investment, 4) unregulated rehabilitation, 5) water resources stoppage.

The above target will be achieved if the Kolaka District PDAM as a means of clean water providers can create a series of good cooperation, between one function with other functions that are interconnected. This is done considering the community's need for clean water is one very urgent thing. Law No. 1 of 1974 and its implementation rules in Government Regulation No. 22 of 1982 on Article 13 
Jurnal Darussalam; Jurnal Pendidikan, Komunikasi dan Pemikiran Hukum Islam Vol. IX, No 1: 13-23. September 2017. ISSN: 1978-4767 (Cetak), ISSN: 2549-4171 (Online)

paragraph (1) stipulates that "Water for drinking purposes is a top priority above all other purposes" (Tirta Darma, 1998).

In an effort to improve the clean water service, Kolaka District PDAM supports government programs towards "Decent Water Decentralization and environmental sanitation of Settlement", then the District Water Supply Chain of Kolaka aims to carry out regional development in the field of clean water in particular and national economic development in general, in order to meet needs of the people's welfare.

Kolaka regency is located on the southeastern island of Sulawesi and geographically in the western part of Southeast Sulawesi Province. The area of Kolaka Regency covers land and islands with an area of $\pm 10,310 \mathrm{~km}^{2}$ (land) and aquatic area with an area of $\pm 20,117 \mathrm{~km}^{2}$ (sea). The morphology of Kolaka Regency in general consists of mountains and hills that extend from north to south. Potential areas or areas for the development of drinking water business are all sub-districts, as each subdistrict and sub-district has a source of raw water that is feasible to be managed into clean water that will be distributed to the community or customers. The following can be seen the potential of raw water sources in Kolaka District seen from the district.

Tabel 1 Source of Raw Water in Kolaka District

\begin{tabular}{|c|l|l|}
\hline No & District & Source of Raw Water \\
\hline 1. & Kolaka & $\begin{array}{l}\text { The river of Kolaka } \\
\text { The river of Mangolo } \\
\text { The river of Huko-Huko }\end{array}$ \\
2. & Pomalaa & The river of Simbune \\
3. & Tirawuta/Rate-Rate & The river of Ladongi \\
4. & Ladongi/Lambandia & The river of Watubangga \\
5. & Watubangga & The river of Mowewe \\
6. & Mowewe & The river of Lana \\
7. & Wolo & The river of Lasusua \\
8. & Lasusua & The river of Pakue \\
9. & Pakue & The river of Batu Putih \\
10. & Batu Putih & The river of Wundulako \\
11. & Wundulako & The river of Tosiba \\
12. & Tosiba/Tamboli & \\
\hline
\end{tabular}

(Source : PDAMs Kolaka District) 
Jurnal Darussalam; Jurnal Pendidikan, Komunikasi dan Pemikiran Hukum Islam Vol. IX, No 1: 13-23. September 2017. ISSN: 1978-4767 (Cetak), ISSN: 2549-4171 (Online)

From 11 sub-districts in Kolaka Regency, only 8 (eight) have coverage of clean water supply services covering 1 (one) city area of Kolaka, 6 (six) areas of the capital city of Sub-district (IKK) covering IKK Pomalaa, IKK Tirawuta, IKK Lambandia, IKK Wolo, IKK Mowewe, IKK Wundulako, and 1 (one) Rural Drinking Water Area (AMP) Tamboli. While 4 (four) other sub-districts have not been served clean water supply facilities. The amount of data of PDAM customers of Kolaka District based on service area coverage are as follows:

Table 2 Number of Customers of Kolaka District PDAM by Area Service

\begin{tabular}{|l|l|l|l|l|}
\hline \multirow{2}{*}{ No } & \multirow{2}{*}{ District } & \multicolumn{3}{|l|}{ Number of Customers } \\
\cline { 3 - 5 } & & $\mathbf{2 0 0 5}$ & $\mathbf{2 0 0 6}$ & $\mathbf{2 0 0 7}$ \\
\hline 1. & Kolaka City & 4.181 & 4.653 & 4.827 \\
\hline 2. & IKK Wundulako & 630 & 679 & 734 \\
\hline 3. & IKK Pomalaa & 698 & 698 & 437 \\
\hline 4. & IKK Mowewe & 242 & 274 & 302 \\
\hline 5. & IKK Rate-Rate & 691 & 745 & 858 \\
\hline 6. & IKK Wolo & 311 & 337 & 392 \\
\hline 7. & IKK Lambandia & - & 367 & 432 \\
\hline 8. & AMP Tamboli & 280 & 355 & 379 \\
\hline
\end{tabular}

(Source: PDAM Kabupaten Kolaka)

In the table above shows an increase in the number of customers each year, although the increase is not too significant. Although there is an increase every year, but it does not mean that the service made by PDAM Kabupaten Kolaka has been optimal and able to satisfy its customers. This is because PDAMs are monopolist companies that have no competitors. As the only regional company that serves the community's need for clean water, the community has no choice, even though the services provided are not in accordance with what they expect.

Various efforts have been made PDAM Kolaka District as a concrete manifestation of care Kolaka PDAM to consumer society. The action are either connecting the installation network or clean water service through the PDAM tank fleet for people who have not reached the distribution pipeline network. However, behind the efforts made most of the community or customers feel the service provided by PDAM Kabupaten Kolaka has not been maximized. Complaints in the form of cloudy water quality, tend to smell, the quantity of water is small and the contents of water that is not smooth is the most often complained of customers or the community. Even in the district capital of Kolaka district, water distribution 
Jurnal Darussalam; Jurnal Pendidikan, Komunikasi dan Pemikiran Hukum Islam Vol. IX, No 1: 13-23. September 2017. ISSN: 1978-4767 (Cetak), ISSN: 2549-4171 (Online)

is done in turns. Some obstacles are experienced by PDAM due to limited facilities and infrastructure, both from the internal environment and from the external environment. Besides the limited ability of existing units in PDAM to reach and monitor service level.

To create service excellence, which in turn will increase customer satisfaction, closely related to the dimension of service quality as a measure of service quality in order to increase customer satisfaction. Through a series of studies on a wide range of service industries, Parasuraman, Zeithml, and Berry (1985) identified ten key dimensions of simplified service quality into five key dimensions: 1). Reliability (reliability), 2). Responsiveness, 3). Assurance, 4) .Empati (empaty), 5). Physical evidence (tangibles).

Based on the above description of the level of customer satisfaction and service quality by connecting the dimensions of service quality as an indicator, the authors try to conduct research with the title "An Analysis of Customer's Satisfaction Level to the Quality of the Services provided by Regional Water Supply Company (PDAM) of Kolaka Regency"

\section{B. Problem Statements}

Based on the background of the above problems, the authors propose the main problem formulation as follows:

1. How is the customer expectation on service quality of PDAM Kolaka Regency?

2. How is the perception of the customer of service quality of PDAM Kolaka Regency?

3. How is customer satisfaction with service quality of PDAM Kolaka Regency?

\section{Research Objectives}

The objectives to be achieved in this research are as follows:

1. To know the customer's expectation on service quality of PDAM Kolaka Regency 
Jurnal Darussalam; Jurnal Pendidikan, Komunikasi dan Pemikiran Hukum Islam Vol. IX, No 1: 13-23. September 2017. ISSN: 1978-4767 (Cetak), ISSN: 2549-4171 (Online)

2. To know the customer perception of service quality of PDAM Kolaka Regency

3. To know customer satisfaction on service quality of PDAM Kolaka Regency

\section{Research Benefits}

This research is expected to provide the following usability:

1. As input for the management of PDAM Kolaka Regency towards improvement of drinking water service faced today and in the future.

2. For Academic this research can be used as reference theoretical studies especially with regard to customer satisfaction and service quality.

3. For other researchers can be used as a complement of the results of existing research, more than that this research can be developed more jauth to know more deeply about things related to PDAM

\section{E. Method Of The Research}

\section{Types of Research}

This research emphasizes descriptive qualitative approach, also supported by quantitative approach. The type of this research is case study research

\section{Location and Time of Study}

The location of this research was conducted at the Regional Water Supply Company (PDAM) Jl.Kayangan Kolaka District. The time of this research is conducted for 2 (two) months starting from July until August 2008

\section{Types and Data Sources}

The types and sources of data used in this study are:

a. Primary data, ie data that has not been processed and directly obtained in the location of research in the form of excavation directly from the community through interviews with guided questionnaires prepared in connection with the customers of PDAM Kolaka District.

b. Secondary data, ie data obtained from sources of PDAM Kolaka Regency that has been processed and closely related to the increase in customer satisfaction 
Jurnal Darussalam; Jurnal Pendidikan, Komunikasi dan Pemikiran Hukum Islam Vol. IX, No 1: 13-23. September 2017. ISSN: 1978-4767 (Cetak), ISSN: 2549-4171 (Online)

\section{Population and Sample}

a. Population, that is all objects whose characteristics will be investigated. In this study the population is the customer of PDAM Kolaka Regency which is included in the coverage area or service area.

b. Sample, ie part of the population whose characteristics will be examined. In this study that will be a sample is part of the customer, which is 150 customer respondents. Considering the relatively large population, the cluster sampling technique used from 8 (eight) sub-districts included in the area or service area, only 3 (three) objects will be investigated, namely Kolaka Kecamata, Wundulako Sub-district and Pomalaa Sub-district.

\section{Data Collection Method}

Data collection methods used in this study as follows:

a. Observation, ie direct observation of the object under investigation by performing data collection in the form of a systematic record in this case concerning the variables studied.

b. Questionnaires or questionnaires distributed to customers to obtain data on matters that can improve customer satisfaction on service of Kolaka District PDAM.

c. Interview, this method aims to complement the data that has not been obtained from the use of questionnaire method as well as control over data that is still in doubt and need adjustment.

\section{Analysis Method}

The method of analysis used to solve the main problems and verification of the hypothesis that has been described is as follows:

a. Descriptive analysis, which is used to describe the level of service and customer satisfaction

b. Analysis of Conformity Level, ie the ratio between perception and customer expectations

c. Importance-Performance Analysis

In this analysis, respondents were asked to assess the importance and level of performance of the variables of service quality dimension and then the average 
Jurnal Darussalam; Jurnal Pendidikan, Komunikasi dan Pemikiran Hukum Islam Vol. IX, No 1: 13-23. September 2017. ISSN: 1978-4767 (Cetak), ISSN: 2549-4171 (Online)

value of importance of attribute and company performance will be analyzed in importance performance matrix. This matrix is very useful as a guide in allocating organizational resources that are limited to specific areas, where performance improvement can have a major impact on customer satisfaction. This matrix also shows certain fields or variables that need to be maintained and variables that need to be reduced priority.

\section{F. The Research Result}

By using conformity level analysis, that is ratio between perception and customer expectation on dimension of service quality of PDAM Kolaka Regency there are 2 (two) things become benchmark, that is:

1. If the level of conformity is $<100 \%$ or below $100 \%$, it means the gap is negative. This is because the service is not in accordance with expectations and customer perceptions. In other words, customers are dissatisfied with the service of Kolaka Regency PDAM

2. If the suitability level $>100 \%$ or above $100 \%$ means the gap is positive. This means that the service is as perceived by the customer as expected by the perceived performance of the customer. This reflects that customers are satisfied with the service of PDAM Kolaka Regency

\section{G. Discussion Of Analysis Result}

From the analysis of attributes or service quality variables, it is known that there is gap (gap) at service of PDAM Kolaka Regency. The existence of the gap (gap) is evident from the analysis of the level of conformity, namely the ratio between perception and customer expectations. From the analysis of the level of conformity shows that the lowest service dimension lies in assurance dimension because the average value of all attributes is negative that is equal to $64,46 \%$. While the highest dimension is tangible dimension, with the degree of suitability of $119.57 \%$

For the Important Performance Analysis result there are 4 quadrants showing the position of each attribute. From the position of each quadrant it is 
Jurnal Darussalam; Jurnal Pendidikan, Komunikasi dan Pemikiran Hukum Islam Vol. IX, No 1: 13-23. September 2017. ISSN: 1978-4767 (Cetak), ISSN: 2549-4171 (Online)

seen that quadrant 1 (top priority) needs serious attention because this quadrant shows the dissatisfaction of customers of Kolaka Regency PDAM. There are 8 (eight) attributes in this quadrant which include: appointment / time in solving customer problem / complaint, appointment / time of service to customers who apply for new clean water, seriousness of employees in completing customer complaints, employee willingness to observe the field when damage to the company's ability to provide a good image for the customer, clean water quality, free from bacteria, not cloudy and odorless, the stability of the quantity of water that reaches the customer, the continuity or continuity of the fixed water distribution without rotating system.

In quadrant 2 (defend) shows attributes whose performance has been as expected by the customer, so that attribute becomes superior in the eyes of the customer. These attributes include: explanation of service procedure of new tide of clean water that is not convoluted, speed operator serve pelaggan by phone, humane attitude of employee in serving customer by not differentiating position and social status of customer, friendliness and courtesy of employee in serving customer, accurate and accurate meter, availability of water bill payment counter in every sub-district.

From the results of research on customers PDAM Kolaka Regency can be concluded that customers are not satisfied with the quality of service PDAM Kolaka. This is because some attributes that are considered important and very urgent for customers, can not be expected by the management of PDAM Kolaka Regency with optimal and better.

\section{H. Conclusion}

1. Highest expectation of Kolaka District PDAM customer which is seen based on interest list that lies in variable or attribute of continuity of water or continuity without rotating system. While the lowest expectations of customers lies in the variables or attributes of employees look neat and attractive. 
Jurnal Darussalam; Jurnal Pendidikan, Komunikasi dan Pemikiran Hukum Islam Vol. IX, No 1: 13-23. September 2017. ISSN: 1978-4767 (Cetak), ISSN: 2549-4171 (Online)

2. The highest performance of PDAM Kolaka Regency viewed based on perception list that is located in explanation of service procedure of new tide of clean water that is not convoluted. While the lowest performance lies in the continuity or continuity of a fixed water distribution without rotating system.

3. Among the 5 (five) dimensions summarized in the quality of service, namely reliability, responsiveness, empathy, assurance and tangible, the dimension of the highest suitability is the tangible dimension, while the dimension with the lowest level of compliance is the assurance dimension.

\section{Recommendation}

From the results of the analysis that has been presented, the suggestions that can be recommended are as follows:

1. Based on the list of interests of customers, should the management to improve service, especially on attributes of relatively high level of importance.

2. The same thing also needs to be done service quality improvement is attribute that show low performance, that is kontuinitas or continuity of water distribution which remain without rotating system. These attributes should get immediate attention, because they are at the highest position on the customer's interest list.

3. Based on the analysis of conformity level, the dimension that shows the biggest negative gap (lowest level of conformity) is the assurance dimension. Therefore, the management of PDAM Kolaka Regency should try to minimize the existing gap by improving the water distribution system so that the water that reaches the customer is guaranteed cleanliness and the water flow is enough continuously without rotating system. Moreover, the variables contained in the assurance dimension is an attribute whose level of importance (hope) is high in the eyes of customers. 
Jurnal Darussalam; Jurnal Pendidikan, Komunikasi dan Pemikiran Hukum Islam

Vol. IX, No 1: 13-23. September 2017. ISSN: 1978-4767 (Cetak), ISSN: 2549-4171 (Online)

\section{References}

2000. Petunjuk Pelaksanaan Survei Kepuasan Pelanggan: Jakarta: Dirjen PEMUDA.

Buchari Alwi. 1992. Manajemen Pemasaran dan Pemasaran Jasa. Bandung: Alphabeta.

Cravens, W. David. 1999. Manajemen Pemasaran dan Kebijakan Perusahaan. Edisi ke 4, Jilid 1 \& 2. Jakarta: Erlangga.

Collier D.A dalam Vincent Casperz. 1994. Manajemen Pelayanan Kualitas Total: Cara Terbaik untuk Memuaskan Pelanggan. Jakarta: Gramedia.

Goetsch, D.I and Davis. 1994. Introduction Total-Quality, Quality, Productivity, Competitiveness, Englewood Vliffs: N. J Prentice Hall Internasional Inc.

Kotler, Philip. 1995. Manajemen Pemasaran. Jilid 1 \& 2. Jakarta: Prenhallindo.

Parasuraman, A,Valerie A.Zeithaml and Leonard L Berry. 1998. Serqual A Multiple-Item Scale For Measuring Consumer Perceptions Of Service Quality. Journal Of Retailing. Vol.64,No.1. Spring.

----. 1994. SERPERV Versus SERQUAL: Reconciling PerformanceBased and Perception-Minus-Ekspectations Measurment of Service Quality. Journal of Marketing. Vol.58, Januari. 